\title{
HYBRIDIZATION AND SELF-COMPATIBILITY IN CONTROLLED POLLINATIONS OF EASTERN NORTH AMERICAN AND ASIAN HEMLOCK (TSUGA) SPECIES
}

\author{
by S.E. Bentz ${ }^{1}$, Louise G.H. Riedel'1 , Margaret R. Pooler², and A.M. Townsend ${ }^{2}$
}

\begin{abstract}
Controlled pollinations were made between five hemlock (Tsuga) species from eastern North America and Asia. Resulting seeds were collected and planted, and more than 5,700 seedlings germinated. A selected number of putative hybrids from each cross were tested for authenticity by DNA fingerprinting. Attempts to hybridize T. canadensis (eastern hemlock) with three Asiatic species were unsuccessful. However, 59 authentic hybrids from crosses between $T$. caroliniana (Carolina hemlock) and T. chinensis (Chinese hemlock) were identified. Crosses between the Asiatic species also were successful. Selfing was demonstrated in all species. Further studies are needed to determine the nature of the crossability barrier between T. canadensis and the Asiatic species. Because eastern native hemlocks are suffering injury from the introduced pest hemlock woolly adelgid (Adelges tsugae), fundamental information of this type may enable plant breeders to successfully hybridize adelgid-tolerant species with the susceptible native hemlock species to create new trees that are both tolerant to the adelgid and horticulturally desirable.
\end{abstract}

Key Words. AFLP; controlled pollination; hemlock; plant hybridization; hemlock woody adelgid; Tsuga.

The eastern North American hemlocks are graceful, valued components of the cultivated and forest landscape as well as important members of riparian and forest ecosystems, providing cooling shade for trout streams and habitat for numerous birds and wildlife (Quimby 1996).

These shade-tolerant trees also are important nursery crops. The estimated value of nursery inventories of Tsuga in 1995 in Tennessee and North Carolina, U.S., was approximately $\$ 34$ million (J.R. Rhea, personal communication, 1995). Tsuga canadensis also is widely planted in the landscape for shade, screening, and ornament, with more than 200 documented selections including upright, weeping, dwarf, and compact cultivars (Swartley 1984).

The two native eastern North American species, Tsuga canadensis (L.) Carrière, the eastern or Canadian hemlock, and T. caroliniana Engelm., the Carolina hemlock, have suffered severe damage and mortality follow- ing infestation by the hemlock woolly adelgid (HWA) Adelges tsugae Annand (Homoptera: Adelgidae) (McClure 1987; McManus et al. 2000). The adelgid, an introduced pest from Asia, was first discovered on the U.S. east coast in the 1950s in Virginia (Gouger 1971) but did not spread rapidly until the 1980s. It is now established in 11 eastern states from Massachusetts to North Carolina (McClure 1987; McClure et al. 1996), occupying about half the natural range of T. canadensis.

Adelgids feed by inserting their stylets through the base of needles into the xylem cells of young twigs, thus depleting food reserves (Young et al. 1995; Shields et al. 1996), causing needle discoloration or loss, stunting, and even death of heavily infested trees, often within several years (McClure 1992; McClure et al. 1996; Young et al. 1995). In New Jersey, 44\% of hemlocks in an approximately 7,000-ha $(17,300-a c)$ hemlock forest suffered moderate to severe defoliation from 1984 through 1994, due mainly to damage from hemlock woolly adelgid (Royle and Lathrop 1997). States outside the known infested range have mounted vigorous quarantines to keep out infested nursery stock and/or to limit transport through their states.

Current research on managing the adelgid focuses on biological control using imported natural insect predators (Montgomery 1999; McClure 2001) and native fungi (Gouli et al. 1997). While chemical control is possible (McClure 1995b), the difficulties, costs, and ecological ramifications make spraying large forest areas or even large single trees impractical.

Considerable genetic variability in adelgid resistance exists among hemlock species. The eastern native hemlocks are considered highly susceptible to the adelgid, with no documented resistance. The two western North American species, T. mertensiana (Bong.) Carrière or T. heterophylla (Raf.) Sarg., on which adelgid has been documented but is not considered a pest problem (Annand 1924), are of limited value in hybridization programs due to their poor adaptation to the east coast environment. Observations and limited investigational 
studies indicate that Asian Tsuga species in the United States show some tolerance to HWA (McClure 1992; R.J. Lewandowski, personal communication). McClure (1992) reported significantly greater survival and fecundity of the adelgid on young trees of T. canadensis and $T$. caroliniana than on the two western American species or on T. diversifolia (Maxim.) Mast., an Asiatic species from northern Japan. Bud kill on the eastern species was about $90 \%$ but less than $1 \%$ on the other species. In Japan and China, HWA also is reported to be a relatively minor pest of T. chinensis (Franch.) E. Pritz., T. diversifolia, and T. sieboldii Carrière, whose impact may be limited by host resistance as well as natural enemies and scattered distribution (McClure 1992, 1995a, 1996; Montgomery 1999). Additionally, no adelgids have been observed on the few T. chinensis and T. diversifolia at the U.S. National Arboretum (Washington, DC) or the Morris Arboretum (Philadelphia, Pennsylvania) in the past 8 years, although HWA-infested trees are located in proximity [12 to 400 $\mathrm{m}(39.4$ to $1,312.3 \mathrm{ft})]$. More variability has been noted for T. sieboldii at the National Arboretum's Washington, DC, and Glenn Dale, Maryland, sites and the Morris Arboretum, where adelgid infestations have ranged from none to severe.

The potential for successful hybridization between adelgid-resistant and susceptible species has not been thoroughly investigated. If successful, such hybridization could lead to the development of new adelgid-resistant hemlocks suitable for use in the eastern United States. There are few reports of hybrids or hybridization between Tsuga species, which are all reported to be diploid with a haploid chromosome number of $n=12$ (Santamour 1963; Sax and Sax 1933). The only reported natural hybrid is that between T. mertensiana and $T$. heterophylla, Tsuga $\times$ jeffreyi (Henry) Henry. In a study of this hybrid, for which morphological and chemical characters were evaluated, Taylor (1972) was able to identify only three hybrids (two living) through chemical analysis of phenolic pigments. Morphological characters were not effective in determining hybridity. Taylor (1972) also reported that several attempts by others to repeat the cross produced no viable seed and concluded that hybridization is possible but occurs with extremely low frequency.

Wang et al. (1997) found no documentation of hybridization between T. canadensis and T. caroliniana. An annual report of the Connecticut Agricultural Experiment Station (1954) noted that 43 crosses, using four T. canadensis and one T. sieboldii as female parents and
T. sieboldii, T. caroliniana, T. chinensis, and T. canadensis as males, produced some seed that would be tested for viability. No further details on the results were given or have been published subsequently ( $\mathrm{H}$. Nienstaedt, personal communication, 1999). Sax and Sax (1933) reported abundant seed set in artificial crosses made between T. caroliniana and T. diversifolia at the Arnold Arboretum (Boston, Massachusetts) but gave no information on the fate of these seeds.

The objective of the present study was to assess the potential for controlled hybridization among different hemlock species in order to examine the degree to which adelgid resistance could be transferred from the Asian species into hybrid offspring, especially hybrids with the eastern North American species. During seven field seasons, we performed self and intra- and interspecific cross-pollinations among five hemlock species.

\section{MATERIALS AND METHODS}

Controlled pollinations between hemlock species were carried out from 1991 through 1995 and 1997 through 1998 and are summarized in Table 1. Parent trees of the following species were used: Tsuga canadensis, T. caroliniana, T.chinensis, T. diversifolia, and T. sieboldii. Trees were located at the U.S. National Arboretum, Washington, DC, and Glenn Dale, Maryland; the Morris Arboretum of the University of Pennsylvania, Philadelphia, Pennsylvania; the former David Fairchild Estate, Bethesda, Maryland; and the Orland E. White Arboretum, University of Virginia, Boyce, Virginia.

Prior to natural anthesis each spring, pollen was collected from branches forced to shed indoors at room temperature, and then stored in glass vials under refrigeration. Current year's pollen was used in most pollinations. Pollen from trees at the Morris Arboretum [air-dried and stored under refrigeration at $4^{\circ} \mathrm{C}$ to $5^{\circ} \mathrm{C}$ $\left(39.2^{\circ} \mathrm{F}\right.$ to $\left.\left.41^{\circ} \mathrm{F}\right)\right]$ from the previous year was used to pollinate trees at the National Arboretum because of the difference in flowering date at the two sites. Previous year's pollen of T. diversifolia from the National Arboretum was used to pollinate T. caroliniana at the Orland E. White Arboretum.

One to two weeks before natural flowering occurred on trees identified for use as female parents (late March through early April in Washington, DC), white nonwoven polyester pollination bags (PBS International, UK) were placed over branches to enclose the unopened female strobili and to exclude foreign pollen. Once the female strobili began to open, slits were cut in 
the bags and pollen was transferred with an artist's brush to the strobili inside the bag. Pollination bags were resealed with adhesive tape and left on the tree. Pollination of the same strobili often was repeated on two or three dates to optimize chances for fertilization. Controls included pollinated selfs and, when possible, unpollinated selfs. Emasculation of branches was carried out in 1994, 1995, 1997, and 1998 following our observation that selfed trees in the 1991 through 1993 crosses produced seed and viable offspring.

Approximately 1 month after pollinations were completed, pollination bags were removed and replaced with open-weave net bags which were left on until cones ripened. Mature cones were collected in the autumn of each year (October and November) and air dried; the resulting seed was extracted by hand. Seeds were sown in flats and moist-stratified at $4^{\circ} \mathrm{C}\left(39.2^{\circ} \mathrm{F}\right)$ for 90 days and then placed in the greenhouse for germination. Seedlings were potted initially into $6 \times 6 \times 12.7 \mathrm{~cm}$ bands $(2.4 \times 2.4 \times 5$ in.) (Anderson Die and Manufacturing Co, Inc., Portland, OR) and then into successively larger containers up to $11.4 \mathrm{~L}$ (3 gal) containing 2:1:1:2 mixture by volume of composted bark, MetroMix 510, perlite, and peat moss.

Molecular analysis of putative hybrid progeny was accomplished using Amplified Fragment Length Polymorphisms (AFLP, Vos et al. 1995), as described in Pooler et al. 2002.

\section{RESULTS AND DISCUSSION \\ Evaluation of AFLP Markers}

For each of the 44 AFLP combinations, 60 to 120 markers were detected for each DNA sample. Of these markers, a range of one to six was selected as reliable polymorphic markers for differentiating between any two parent combinations. In determining hybridity, we followed five to eleven markers specific to T. canadensis male parents, five to six markers specific to T. caroliniana, two to ten markers specific to T. chinensis, four to twelve markers specific to T. diversifolia, and three to nine markers specific to T. sieboldii.

\section{Interspecific Hybridization}

Controlled pollination yielded a total of more than 5,700 seedlings (Table 1). Unfortunately, attempts to hybridize T. canadensis with each of the three Asian species were unsuccessful (Table 1). In contrast, controlled pollinations between T. caroliniana and T. chinensis produced 59 authentic hybrids. These results are consistent with a recently published phylogenetic analysis (Vining 1999) placing T. caroliniana within the same clade of Asian species used in our studies, thus indicating that T. caroliniana may be more closely related to the Asian species than is T. canadensis. No hybrids between $T$. caroliniana and T. diversifolia have been detected so far. However, our attempts in this cross were complicated by difficult access to suitable trees and, in the second year of trial, the necessity of using stored pollen from the previous year. T. caroliniana $\times$ T. sieboldii crosses were not attempted for these same reasons.

Cross compatibility between each of the Asiatic species was high (Table 1). For example, crosses between T. chinensis and T. sieboldii and T.chinensis and T. diversifolia (as male or female parents) produced hybrids. Hybrids were also identified between T. diversifolia and T. sieboldii with T. diversifolia as female. These results are also consistent with the phylogeny proposed by Vining (1999).

Although few interspecific hybrids were detected with eastern north American Tsuga spp., results were occasionally ambiguous. For example, four of the T. canadensis $\times$ $T$. chinensis seedlings exhibited a $T$. chinensis-specific marker, but not consistently. Although paternal inheritance of chloroplast DNA has been reported in conifers (Wang et al. 1997), this phenomenon was not examined in our study and should not have had an impact on our ability to detect hybrids. We plan to investigate whether genetic distance correlates with the ability to hybridize between species.

\section{Selfing}

Selfing was detected in all species tested but was especially pronounced in the two American species, with 367 selfs from T. caroliniana and 533 from T. canadensis. If this level of self-compatibility occurs in natural forests, then a relatively high degree of homozygosity and genetic uniformity would be expected to occur in these two species. A considerable degree of uniformity has been demonstrated in T. canadensis (Zabinski 1992). Further studies are need to determine the level of selfing in natural populations of these two species.

The few reports on north American hemlock breeding provide little information on the potential for selfing or apomixis in the species. Neinstaedt and Kriebel (1955) reported that no seeds were produced in any unpollinated controls of T. canadensis in experiments evaluating types of pollination bags. M. Meagher (Canadian Forest Service, retired, personal communication, 2001) noted that he has selfed western hemlock, T. heterophylla, with 
Table 1. Summary of controlled pollinations in Tsuga.

\begin{tabular}{|c|c|c|c|c|c|c|c|c|}
\hline \multirow[b]{2}{*}{$\begin{array}{r}\text { Female parent/ } \\
\text { male parent }\end{array}$} & \multirow[b]{2}{*}{$\begin{array}{l}\text { No. of } \\
\text { female } \\
\text { parents }\end{array}$} & \multirow[b]{2}{*}{$\begin{array}{l}\text { No. of } \\
\text { male } \\
\text { parents }\end{array}$} & \multirow[b]{2}{*}{$\begin{array}{l}\text { No. of } \\
\text { years } \\
\text { attempted }\end{array}$} & \multirow[b]{2}{*}{$\begin{array}{l}\text { No. of } \\
\text { cones }\end{array}$} & \multirow[b]{2}{*}{$\begin{array}{l}\text { No. of } \\
\text { seedlings } \\
\text { germinated }\end{array}$} & \multirow{2}{*}{$\begin{array}{l}\text { No. of parental } \\
\text { combinations } \\
\text { producing } \\
\text { progeny/ } \\
\text { total combinations } \\
\text { attempted }\end{array}$} & \multicolumn{2}{|c|}{ AFLP analysis } \\
\hline & & & & & & & $\begin{array}{l}\text { No. of } \\
\text { seedlings } \\
\text { examined } \\
\end{array}$ & $\begin{array}{l}\text { No. of } \\
\text { seedlings } \\
\text { verified as hybrids }\end{array}$ \\
\hline \multicolumn{9}{|l|}{ T. canadensis } \\
\hline$\times$ self & 6 & 6 & 6 & 492 & 553 & $5 / 6$ & - & - \\
\hline$\times T$. canadensis & 6 & 5 & 6 & 318 & 1992 & 9/11 & - & - \\
\hline$\times$ T. caroliniana & 2 & 2 & 1 & 223 & 447 & $3 / 4$ & 6 & 0 \\
\hline$\times T$. chinensis & 6 & 2 & 6 & 949 & 543 & $5 / 9$ & 36 & 0 \\
\hline$\times T$. diversifolia & 4 & 3 & 3 & 523 & 333 & $8 / 8$ & 36 & 0 \\
\hline$\times$ T. sieboldii & 3 & 2 & 3 & 363 & 530 & $6 / 6$ & 39 & 0 \\
\hline \multicolumn{9}{|l|}{ T. caroliniana } \\
\hline$\times$ self & 2 & 2 & 3 & 118 & 367 & $2 / 2$ & - & - \\
\hline$\times$ T. canadensis & 2 & 2 & 2 & 62 & 60 & $2 / 3$ & 10 & 1 \\
\hline$\times$ T. caroliniana & 2 & 2 & 3 & 60 & 84 & $2 / 2$ & - & - \\
\hline$\times T$. chinensis & 2 & 2 & 3 & 106 & 186 & $2 / 2$ & 49 & 43 \\
\hline$\times T$. diversifolia & 2 & 2 & 3 & 132 & 345 & $1 / 4$ & 11 & 0 \\
\hline$\times$ T. sieboldii & - & - & - & - & - & - & - & - \\
\hline \multicolumn{9}{|l|}{ T. chinensis } \\
\hline$\times$ self & 2 & 2 & 5 & 171 & 7 & $2 / 2$ & - & - \\
\hline$\times T$. canadensis & 2 & 4 & 5 & 607 & 7 & $4 / 6$ & 4 & 0 \\
\hline$\times$ T. caroliniana & 2 & 3 & 3 & 74 & 19 & $2 / 3$ & 16 & 16 \\
\hline$\times T$. chinensis & 2 & 2 & 2 & 38 & 83 & $2 / 2$ & - & - \\
\hline$\times T$. diversifolia & 2 & 2 & 3 & 78 & 13 & $2 / 2$ & 13 & 11 \\
\hline$\times$ T. sieboldii & 1 & 2 & 3 & 91 & 35 & $2 / 2$ & 27 & 27 \\
\hline \multicolumn{9}{|l|}{ T. diversifolia } \\
\hline$\times$ self & 3 & 3 & 4 & 157 & 5 & $1 / 3$ & - & - \\
\hline$\times$ T. canadensis & 3 & 3 & 4 & 470 & 0 & $0 / 7$ & - & - \\
\hline$\times$ T. caroliniana & 2 & 3 & 3 & 176 & 0 & $0 / 4$ & - & - \\
\hline$\times T$. chinensis & 1 & 1 & 3 & 87 & 42 & $1 / 1$ & 10 & 10 \\
\hline$\times T$. diversifolia & 3 & 2 & 3 & 81 & 73 & $3 / 3$ & - & - \\
\hline$\times$ T. sieboldii & 1 & 2 & 3 & 171 & 21 & $2 / 2$ & 11 & 10 \\
\hline \multicolumn{9}{|l|}{ T. sieboldii } \\
\hline$\times$ self & 2 & 2 & 3 & 221 & 2 & $1 / 2$ & - & - \\
\hline$\times T$. canadensis & 2 & 3 & 3 & 345 & 2 & $2 / 6$ & 1 & 0 \\
\hline$\times$ T. caroliniana & 1 & 1 & 1 & 58 & 1 & $1 / 1$ & - & - \\
\hline$\times T$. chinensis & 2 & 1 & 3 & 119 & 26 & $2 / 2$ & 23 & 22 \\
\hline$\times T$. diversifolia & 2 & 2 & 3 & 129 & 0 & $0 / 4$ & - & - \\
\hline$\times$ T. sieboldii & 2 & 2 & 1 & 36 & 21 & $2 / 2$ & - & - \\
\hline
\end{tabular}

variable success (defined as the percentage of filled seed). Asker and Jerling (1992) in their review of apomixis note only that "reports on apomixis in gymnosperms are few and uncertain" and included no references to Tsuga.

When the production of viable seedlings from cones of selfed individuals, particularly in T. caroliniana and T. canadensis, was first observed following the germination and growth of 1992 seedlings, we began emasculating branches of all trees used as females in hybrid crosses beginning in 1994. The numbers of seedlings germinating per cone dropped by more than half following emasculation of T. canadensis and T. caroliniana in crosses with T. chinensis (data not presented). Complete emasculation is difficult in Tsuga because male cones do not develop synchronously and consequently are not always detected after emasculation. Thus, contamination by self pollen within the bags (or potentially at the time of pollination or due to bag closure failure) could partially explain the 
large numbers of seedlings resulting from T. canadensis and T.caroliniana crosses.

\section{CONCLUSIONS}

Interspecific hybrids between the eastern North American species T. caroliniana and the Asian species T. chinensis and between the Asian species T. chinensis, T. diversifolia, and T. sieboldii were produced through controlled pollinations and identified using AFLP technology. A single plant of the cross T. caroliniana $\times$ T. canadensis also was identified. No authentic hybrids between T. canadensis and the three Asian species were obtained, indicating a potential crossability barrier. The nature of this barrier is unknown at this time and will require further research. All species, when selfed, produced significant numbers of cones and some viable seedlings.

Viable hybrid seedlings between the adelgid-susceptible T. caroliniana and more adelgid-tolerant T. chinensis will provide an opportunity to examine the inheritance of adelgid resistance as well as assess the landscape potential of these interspecific hybrids. Based on our results and recent proposed phylogeny of Tsuga (Vining 1999), we may expect that future crosses between T. caroliniana and the other hemlock woolly adelgid-tolerant species, $T$. diversifolia or T. sieboldii, might be possible and may provide valuable additional sources of resistance and/or cold-hardiness.

\section{LITERATURE CITED}

Annand, P.N. 1924. A new species of Adelges (Hemiptera: Phylloxeridae). Pan-Pac. Entomol. 1:79-82.

Asker, S., and L. Jerling. 1992. Apomixis in Plants. CRC Press, Boca Raton, FL. 298 pp.

Connecticut Agricultural Experiment Station. 1954. Record of the Year 1953-54. The Connecticut Agricultural Experiment Station, New Haven, CT. 74 pp.

Gouger, R.J. 1971. Control of Adelges tsugae on hemlock in Pennsylvania. Sci. Tree Topics 3:1-9.

Gouli, S., B.L. Parker, and M. Skinner. 1997. Isolation of fungi associated with hemlock woolly adelgid (Homoptera: Adelgidae). J. Invert. Path. 70:76-77.

McClure, M.S. 1987. Biology and Control of Hemlock Woolly Adelgid. Bulletin 851 of the Connecticut Agricultural Experiment Station. 9 pp.

McClure, M.S. 1992. Hemlock woolly adelgid. Am. Nurseryman 175(6):82-89.

McClure, M.S. 1995a. Diapterobates humeralis (Oribatida: Ceratozetidae): An effective control agent of hemlock woolly adelgid (Homoptera: Adelgidae) in Japan. Environ. Entomol. 24(5):1207-1215.

McClure, M.S. 1995b. Managing Hemlock Woolly Adelgid in Ornamental Landscapes. Bulletin 925 of the Connecticut Agricultural Experiment Station, New Haven, CT. 7 pp.
McClure, M.S. 1996. Woolly Bully. Am. Nurseryman 138(11):52-57.

McClure, M.S. 2001. Biological Control of Hemlock Woolly Adelgid in the Eastern United States. FHTET-2000-08. USDA Forest Service, Forest Health Technology Enterprise Team, Morgantown, WV. 10 pp.

McClure, M.S., S.M. Salom, and K.S. Shields. 1996. Hemlock Woolly Adelgid. FHTET-96-35. USDA Forest Service, Forest Health Technology Enterprise Team, Morgantown, WV. 14 pp.

McManus, K.A., K.S. Shields, and D.R. Souto (Eds.). 2000. Proceedings: Symposium on Sustainable Management of Hemlock Ecosystems in Eastern North America, 22-24 June 1999, Durham, NH. GTR-NE-267. USDA Forest Service, Northeastern Research Station, Newtown Square, PA. 237 pp.

Montgomery, M.E. 1999. Woolly adelgids in the southern Appalachians: Why they are harmful and prospects for control, pp 47-57. In Gibson, P. and C. R. Parker (Eds.). Proceedings of the Southern Appalachian Biological Control Initiative Workshop, 26-27 September 1996. FHTET-98-14. USDA Forest Service, Forest Health Technology Enterprise Team, Morgantown, WV.

Neinstaedt, H., and H.B. Kriebel. 1955. Controlled pollination of eastern hemlock. For. Sci. 1(2):115-120.

Pooler, M.R., L.G.H. Riedel, S.E. Bentz, and A.M. Townsend. 2002. Molecular markers used to verify interspecific hybridizations between hemlock (Tsuga) species. J. Am. Soc. Hortic. Sci. (in press).

Quimby, J.W. 1996. Value and importance of hemlock ecosystems in the eastern United States, pp 1-8. In Salom, S.M., T.C. Tigner, and R.C. Reardon (Eds.). Proceedings of the First Hemlock Woolly Adelgid Review, Charlottesville, VA. FHTET 96-10. USDA Forest Service, Forest Health Technology Enterprise Team, Morgantown, WV.

Royle, D.D., and R.G. Lathrop. 1997. Using Landsat thematic mapper data and change detection techniques to monitor hemlock forest health. For. Sci. 43(3)327-335.

Santamour, F.S. Jr. 1963. Chromosome number in Tsuga. Morris Arboretum Bull. 14:51.

Sax, K., and H.J. Sax. 1933. Chromosome number and morphology in the conifers. J. Arnold Arboretum 14: 356-375.

Shields, K.S., R.F. Young, and G.P. Berlyn. 1996. Hemlock woolly adelgid feeding mechanisms, pp 36-41. In Salom, S.M., T.C. Tigner, and R.C. Reardon (Eds.). Proceedings of the First Hemlock Woolly Adelgid Review, Charlottesville, VA. FHTET 96-10. USDA Forest Service, Forest Health Technology Enterprise Team, Morgantown, WV.

Swartley, J.C. 1984. The cultivated hemlocks. Timber Press, Portland, OR. 186 pp.

Taylor, R.J. 1972. The relationship and origin of Tsuga heterophylla and Tsuga mertensiana based on phytochemical and morphological interpretations. Am. J. Bot. 59(2):149-157.

Vining, T.F. 1999. Molecular Phylogenetics of Pinaceae. Ph.D. dissertation, University of Maine, Orono, ME. 75 pp. 
Vos, P., R. Hogers, M. Bleeker, M. Reijans, T. van de Lee, M. Hornes, A Frijters, J. Pot, J. Peleman, M. Kuiper, and M. Zabeau. 1995. AFLP: A new technique for DNA fingerprinting. Nucleic Acids Res. 23:4407-4414.

Wang, C., M.H. Perlin, R.R. van Stockum Jr., C.H. Hamilton, and D.B. Wagner. 1997. Chloroplast DNA polymorphisms in Tsuga canadensis and Tsuga caroliniana. Can. J. For. Res. 27(9):1329-1335.

Young, R.F., K.S. Shields, and G.P. Berlyn. 1995. Hemlock woolly adelgid (Homoptera: Adelgidae): Stylet bundle insertion and feeding sites. Ann. Entomol. Soc. Am. 88:827835.

Zabinski, C. 1992. Isozyme variation in eastern hemlock. Can. J. For. Res. 22:1838-1842.

Acknowledgments. This research was funded in part by USDA Forest Service Forest Health Technology Enterprise Team Agreement 11-2442-97-05. We are grateful to the Morris Arboretum of the University of Pennsylvania, Philadelphia, Pennsylvania; R.J. Lewandowski, Director, Mt. Cuba Center for the Study of Piedmont Flora and formerly Director of Horticulture, Morris Arboretum; The Orland E. White Arboretum, Boyce, Virginia; and David E. Carr, Curator and Assistant Professor, University of Virginia, for cooperation, assistance, and access to plant materials. For editorial comments, we thank our anonymous reviewers. We thank Thomas E. Abell, USNA, for invaluable support of plant breeding activities and daily plant maintenance. We acknowledge the leadership and support of our colleague and friend, Frank S. Santamour, Jr., in pursuing this investigation.

\section{${ }^{1 *}$ Horticulturist \\ ${ }^{2}$ Research Geneticist \\ U.S. National Arboretum, USDA-ARS \\ 3501 New York Ave., N.E. \\ Washington, DC 20002, U.S.}

* Corresponding author: S.E. Bentz.

Résumé. Des pollinisations contrôlées ont été faites entre cinq espèces de pruches (Tsuga spp.) d'Amérique du Nord et d'Asie. Les semences produites ont été recueillies et plantées, et plus de 5700 semences ont germées. Un nombre sélectionné d'hybrides ont été testés en regard de leur authenticité grâce à un test d'ADN. Les tentatives pour hybrider T. canadensis (pruche de l'Est du Canada) avec trois espèces asiatiques ont été infructueuses. Cependant, 59 hybrides authentiques provenant de T. caroliniana (pruche de Caroline) avec T. chinensis (pruche de
Chine) ont été identifiés. Des croisements entre les diverses espèces asiatiques ont aussi été couronnés de succès. L'individualité a été démontrée pour toutes les espèces. Des études supplémentaires sont requises pour déterminer la nature de la barrière au niveau du croisement entre $T$. canadensis et les espèces asiatiques. Étant donné que les espèces indigènes de pruches de l'Est sont sujet à souffrir de dommages provenant de la cochenille floconneuse de la pruche (Adelges tsugae), un parasite introduit, des informations fondamentales de ce type pourraient permettre aux hybrideurs de végétaux de développer des espèces hybrides tolérantes à cette cochenille à partir des espèces indigènes susceptibles afin de créer de nouveaux arbres qui sont à la fois tolérants à cette cochenille et désirables au niveau horticole.

Zusammenfassung. Zwischen 5 Tsuga-Arten aus dem Osten Nordamerikas und Asien wurden kontrollierte Befruchtungen vorgenommen. Die entstandenen Samen wurden gesammelt und gepflanzt. Über 5.700 Sämlingen entstanden dabei. Eine Auswahl von putativen Hybriden jeder Kreuzung wurde aufAuthentizität durch eine DNA-Untersuchung getestet. Die versuche, Tsuga canadensis mit drei asiatischen Arten zu kreuzen, scheiterten. Trotzdem konnten 59 authentische Hybriden zwischen $T$. canadensis und $T$. chinensis identifiziert werden. Die Kreuzungen zwischen den asiatischen Arten waren ebenfalls erfolgreich. Bei allen Arten wurde Selbstnachwuchs demonstriert. Um die Grenze der Kreuzungsbarriere zwischen T. canadensis und den asiatischen Arten näher zu bestimmen, sind weitere Studien erforderlich. Weil die östlichen einheimischen Arten durch eingeführte Krankheiten (Schildläuse: Adelges tsugae) leiden, könnten fundamentale Informationen dieser Art die Pflanzenzüchter in die Lage versetzen, erfolgreich schildlausresistente Arten zu kreuzen und zu züchten, um neue Bäume $\mathrm{zu}$ kreieren, die sowohl tolerant als auch gartenbautechnisch wünschenswert sind.

Resumen. Se realizaron polinizaciones controladas entre cinco especies de abetos (Tsuga) del este de Norte América y Asia. Las semillas resultantes fueron colectadas y plantadas, y se obtuvieron más de 5,700 brinzales. Fue probado para autenticidad por DNA un número seleccionado de híbridos putativos de cada cruza. No resultaron exitosos los intentos para hibridizar T. canadensis (abeto del este) con tres especies asiáticas. Sin embargo, fueron identificados 59 híbridos auténticos de las cruzas entre T. caroliniana (abeto de Carolina) y T. chinensis (abeto chino). Las cruzas entre las especies asiáticas también fueron exitosas. Se requieren más estudios para determinar la naturaleza de la barrera de cruzabilidad entre $T$. canadensis y las especies asiáticas. Debido a que las especies de abetos nativos están recibiendo el ataque de plagas introducidas (Adelges tsugae), este tipo de información habilita a los viveristas para hibridizar exitosamente especies tolerantes a la plaga con las especies nativas de abetos; para crear nuevos árboles que sean a la vez tolerantes a la plaga y horticulturalmente deseables. 